\title{
Correction to: Decisional Balance Inventory (DBI) Adolescent Form for Smoking: Psychometric Properties of the Persian Version
}

Maryam Khazaee-Pool ${ }^{1 *}$, Tahereh Pashaei ${ }^{2,7}$, Koen Ponnet $^{3,4}$, Fatemeh Jafari ${ }^{5}$ and Rashin Alizadeh ${ }^{6}$

\section{Correction}

After publication of the article [1], it has been brought to our attention that the first and last names of the third author were transposed in the original article. The author was published as "Ponnet Koen" where in fact the correct name is "Koen Ponnet". The original article has been revised to reflect this.

\footnotetext{
Author details

'Department of Health Education and Promotion, School of Public Health, Zanjan University of Medical Sciences, Zanjan, Iran. ${ }^{2}$ Social Determinants of Health Research Center, Kurdistan University of Medical Sciences, Sanandaj, Iran. ${ }^{3}$ Department of Communication Sciences, Ghent University, Ghent, Belgium. ${ }^{4}$ Department of Communication Sciences, University of Antwerp, Antwerp, Belgium. ${ }^{5}$ Department of Public Health, School of Public Health, Zanjan University of Medical Sciences, Zanjan, Iran. ${ }^{6}$ Department of Health Education and Promotion, School of Health, Tehran University of Medical Sciences, Tehran, Iran. ${ }^{7}$ Department of Public Health, Faculty of Health,

Kurdistan University of Medical Sciences, Sanandaj, Iran.
}

Received: 20 November 2017 Accepted: 21 November 2017

Published online: 30 November 2017

\section{Reference}

1. Khazaee-Pool M, Pashaei T, Ponnet K, Jafari F, Alizadeh R. Decisional balance inventory (DBI) adolescent form for smoking: psychometric properties of the Persian version. BMC Public Health. 2017;17(1) https://doi.org/10.1186/ s12889-017-4425-2.

\footnotetext{
*Correspondence: khazaee.m@zums.ac.ir; khazaie_m@yahoo.com 'Department of Health Education and Promotion, School of Public Health, Zanjan University of Medical Sciences, Zanjan, Iran

Full list of author information is available at the end of the article
}

Submit your next manuscript to BioMed Central and we will help you at every step:

- We accept pre-submission inquiries

- Our selector tool helps you to find the most relevant journal

- We provide round the clock customer support

- Convenient online submission

- Thorough peer review

- Inclusion in PubMed and all major indexing services

- Maximum visibility for your research

Submit your manuscript at www.biomedcentral.com/submit \section{(1)}

